DIW BERLIN

Discussion

Papers
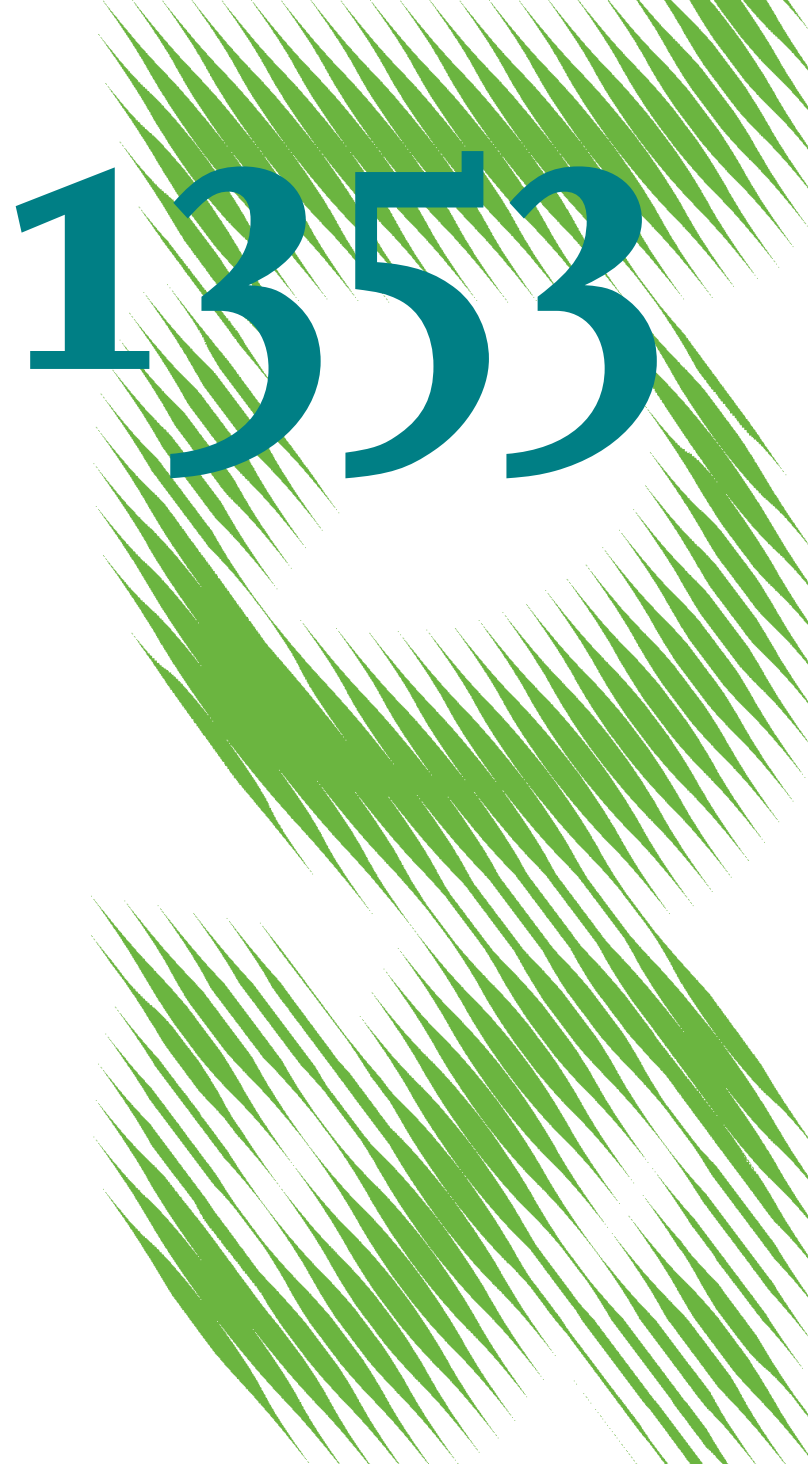

Financing Patterns of Innovative SMEs and the Perception of Innovation Barriers in Germany 
Opinions expressed in this paper are those of the author(s) and do not necessarily reflect views of the institute.

IMPRESSUM

(C) DIW Berlin, 2014

DIW Berlin

German Institute for Economic Research

Mohrenstr. 58

10117 Berlin

Tel. $+49(30) 89789-0$

Fax +49 (30) $89789-200$

http://www.diw.de

ISSN print edition $1433-0210$

ISSN electronic edition 1619-4535

Papers can be downloaded free of charge from the DIW Berlin website:

http://www.diw.de/discussionpapers

Discussion Papers of DIW Berlin are indexed in RePEc and SSRN:

http://ideas.repec.org/s/diw/diwwpp.html

http://www.ssrn.com/link/DIW-Berlin-German-Inst-Econ-Res.html 


\title{
Financing patterns of innovative SMEs and the perception of innovation barriers in Germany
}

\author{
Heike Belitz (DIW Berlin) \& \\ Anna Lejpras (BSP Business School Berlin Potsdam) ${ }^{1}$
}

January 2014

\begin{abstract}
We analyze the role of public support in the financing pattern of R\&D in German SMEs and their assessment of financing conditions in the context of other framework conditions for innovation. In Germany, there is a diversity of overall well-funded technology-neutral and technologyspecific programs providing grants to R\&D and innovation projects. Different types of SMEs access public funding for R\&D and innovation activities to varying degrees. Using an extensive sample of 2,700 German SMEs that participated in public R\&D promotion programs during the 2005-2010 period, we identify four groups of companies with different patterns of public and private sources of R\&D finance, such as own capital, grants, private and subsidized loans.

The firms in our sample are generally positive about public financing of R\&D in Germany in 2010. Despite the different funding patterns, we find only slight variations in this assessment across the four groups of subsidized SMEs. Nevertheless, medium-sized R\&D companies (often with external equity investment) that have to finance the market introduction of innovations without a track record, appear to suffer from deficiencies in the provision of loans. Further, the companies perceive obstacles to innovation primarily in the non-financial sphere, namely the supply of skilled personnel, market regulation and competition conditions. Therefore, future work on innovation policies for SMEs should put greater emphasis on the non-financial external framework conditions for firm R\&D and innovative activities.
\end{abstract}

JEL-Classification: 014, O25, O38, L20

Keywords: R\&D promotion, Financing of R\&D, Small and medium sized enterprises, Barriers to innovation

\footnotetext{
${ }^{1}$ We would like to thank Alexander Eickelpasch for discussions and suggestions.
} 


\section{Introduction}

Innovative small and medium-sized enterprises (SMEs) are key actors in the national and regional innovation systems. Compared to large firms, they face some additional disadvantages when engaging in $R \& D$ and innovation activities, beyond those usually considered that pertain to the market failures comprised of external effects, information asymmetries in risk assessment, and the indivisibility of R\&D. Indeed, SMEs suffer more from constraints to external R\&D funding opportunities, benefit less from knowledge spillovers owing to their limited absorption capacity, and are often less capable of imposing innovations on the market. Further, in many cases, they can only achieve the necessary level of R\&D capacity and access to the diversity of the requisite technological expertise through cooperative partnerships. Small companies usually cannot contribute innovation risk across a range of projects, they have more limited opportunities to exploit economies of scale, and they must compete with larger companies for skilled staff (Dirk Czarnitzki \& Delanote, 2012; Hall, 2010; Schneider \& Veugelers, 2010; Veugelers, 2008). As a result, SMEs tend to underinvest in R\&D from a socio-economic perspective. In order to alleviate these difficulties to innovation-especially those relating to the financial limitationsand, thus, align the R\&D expenditure to social desirable level, governments promote R\&D and innovation by SMEs through direct and indirect financial measures.

In this paper, we analyze how subsidized German SMEs use private and public sources to finance their R\&D activity, such as own capital (including external equity investment), grants, and (subsidized) loans. In Germany, due to a highly diverse range of programs on the national, the federal states and the EU level, SMEs principally have the possibility of obtaining R\&D subsidies from different sources. Thus, the question arises whether there is an "optimal mix" of these programs and private sources to finance $R \& D$. To assess the functioning and efficiency of R\&D subsidy programs in Germany, one first needs to develop an understanding of the overall allocation of subsidies in SMEs. Therefore, we provide some insights into the much neglected aspects, i.e., who (which type of firms) actually participates in which type of public measures and why (Tanayama, 2009). Since individual firms receive different amounts of public funds, R\&D subsidies may give different incentives to conduct $R \& D$ and/or to change innovative behavior. Hence, our main goal is to explore this heterogeneity of subsidized firms taking the financing structure of R\&D activity into consideration.

Yet, note that public R\&D support-even though important and in the focus of technology policy - is still only one factor relating to the scale of R\&D and innovation activity of firms and to their innovation performance. Indeed, there are many other external framework conditions, beyond the financial constraints, that may have significant positive or negative effects on SMEs' R\&D and innovation, such as market conditions (labor market, supply/sales markets), bureaucratic hurdles 
(restrictive laws and regulations) access to knowledge and information or intellectual property rights (see e.g., Aghion, Bloom, Blundell, Griffith, \& Howitt, 2005; Aghion, Blundell, Griffith, Howitt, \& Prantl, 2009; Hashi \& Stojcic, 2010; Hölzl \& Janger, 2012; Mohnen, Palm, Loeff, \& Tiwari, 2008; Veugelers, 2008). However, public $R \& D$ promotion in the context of other framework conditions for $R \& D$ and innovation of SMEs has been scantly investigated so far; an oversight this paper intends to address as well.

Considering the significant expansion of public support of R\&D and innovation activity in SMEs in response to the 2008/09 crisis, we expect that the importance of financial constraints for German SMEs has decreased, in general. Nevertheless, one could suppose that the scarcity of the financing resources is still a great problem for some types of SMEs - especially, young innovative companies (YICs). In economic literature and technology policy these firms get special attention because they are expected to bring a great number of break-through innovations and to foster growth and job creation (Dirk Czarnitzki \& Delanote, 2012; Hall, 2010; Schneider \& Veugelers, 2010). Hence, we investigate how important financial and non-financial constraints are for different types of subsidized SMEs.

Our empirical analysis is based on a unique and representative survey data on 2,708 German SMEs that participated in public R\&D promotion programs during the 2005-2010 period. In the first step of our analysis, we identify four types of SMEs employing a cluster analysis that uses information on the internal and external financing sources of $R \& D$ activity. In the second step, we analyze differences between the SMEs groups in respect to firm characteristics and innovative behavior. Special emphasis is on the distribution of YICs across the revealed types of SMEs to find out whether they tend to follow one specific financing pattern of R\&D activity. Finally, we explore whether there are differences in the assessment of the importance and the quality of various financial and non-financial framework conditions between the identified groups of SMEs.

The next section describes the dataset and the methodology used in the paper. Section 3 depicts the found four types of subsidized SMEs. Section 4 discusses the differences in the innovation behavior between the SME groups and shows the analysis results of the usage of different sources and types of R\&D programs by the SMEs clusters. In Section 5, we analyze the self-assessment of financial and nonfinancial framework conditions for innovation by the clusters of subsidized SMEs. The final section provides a summary and conclusions.

\section{Data and methodology}

Our analysis is based on the micro-level data collected via survey by the German Institute for Economic Research (DIW Berlin) in 2011, on behalf of the German Federal Ministry of Economics and Technology (BMWi). This survey was sent to approximately 12,000 German firms that obtained public 
funding that financed R\&D projects over the 2005-2010 period. Approximately 3,000 firms responded to the survey, covering more than one-third of total SMEs that were federally subsidized in $2010 .^{2}$ Hence, our survey data is quite representative for SMEs publicly supported in 2010. Further, compared to the Mannheim Innovation Panel, ${ }^{3}$ our dataset has two advantages that make it particularly suitable for our study purposes: (1) it also includes micro-enterprises; and (2) it contains information on both the amount and the sources of R\&D financing in SMEs.

Once companies with more than 250 employees are removed, the final sample contains 2,708 SMEs-1,429 of those are manufacturing firms; 828 and 451 are engaged in services and other sectors (like construction or handcraft), respectively. The questionnaire consists of more than 20 questions eliciting general information about the firm, its $R \& D$ and innovative activities (together with the pattern of $R \& D$ financing), the participation in public $R \& D$ support programs, as well as the assessment of various framework conditions for R\&D and innovation activity. Table A 1 of the Appendix presents some descriptive statistics of subsidized SMEs included in our sample.

In the first step of our empirical analysis, we aim at synthesizing highly heterogeneous subsidized SMEs into a manageable and interpretable set of typologies with respect to the R\&D financing behavior. An effective way and also common practice to do this is employing the multivariate technique-cluster analysis (Evangelista \& Vezzani, 2010; Hollenstein, 2003). In this case, publicly supported SMEs with as similar as possible R\&D financing pattern are clustered in groups rendering the differences between the groups as large as possible. The cluster analysis was carried out using four variables: three variables measuring the share of $R \& D$ financing sources-internal funding, public R\&D subsidies and other external funding (public and private credits)—over total R\&D expenditure in 2010, as well as a dummy indicating R\&D firms, i.e., companies having R\&D expenditures higher than the total turnover in 2010. We include the latter variable in the cluster analysis because we suppose that these firms are concentrated on $R \& D$ activities. Compared to other companies, that finance R\&D from their own business activities, $R \& D$ firms may follow a different pattern of financing their R\&D activity (often with an external equity investment).We realize that looking at the $R \& D$ financing structure for only one year may raise a potential concern. However, there is pervasive evidence in the existing literature that indicates that the subsidies granted to a firm are relatively persistent over time, so that a firm whose R\&D activity was subsidized in the past is more likely to be subsidized again (Zúñiga-Vicente, Alonso-Borrego, Forcadell, \& Galán, 2012). Analyzing German innovative firms, Aschhoff (2010) found participation in the direct funding scheme to be quite stable, as well. Hence, we can expect that the clusters-each using public

\footnotetext{
${ }^{2}$ According to the information of the Federal Ministries, we estimate a total of 8,500 SMEs were supported by a project grant of the Federal Government in 2010.

${ }^{3}$ The Mannheim Innovation Panel is the annual innovation survey of German companies and part of Eurostat's Europe-wide Innovation Survey.
} 
$R \& D$ support to a different extent-found in our analysis, are quite stable over the medium-term assuming substantially equivalent conditions of public promotion. ${ }^{4}$

In order to interpret the identified clusters and check the internal consistency, we estimate probit regressions, which relate the likelihood of being assigned to each specific cluster to various firm characteristics and abilities, such as firm size, R\&D and innovation activities, labor productivity or industry sector. Additionally, we take firm participation in public R\&D support programs at different levels (that is, at the Federal Government, federal states (Länder) and EU levels) into consideration. In a further step, the relationship between SMEs' patterns of the R\&D financing behavior and participation in different types of R\&D support programs is explored based on probit regressions. ${ }^{5}$ Finally, we investigate the importance of various framework conditions (employing probit models) and obstacles to innovation (using ordered probit regressions) from the viewpoint of the identified types of SMEs. Note that we also control for firm size, R\&D intensity and economic sector in the second and third analysis steps. Table 1 sets out a more detailed depiction of the variables used in each step of the econometric analysis.

[Table 1 near here]

\section{$3 \quad$ R\&D financing patterns of subsidized SMEs}

Basically, there are three sources for financing R\&D and innovation projects: (1) internal sources, that is retained profits or (new) equity, (2) external sources such as bank loans or other debt contracts (including subsidized loans), and (3) external public sources like government grants or tax credits. There is a whole branch of theoretical and empirical literature illustrating that firms indeed first and foremost use internal funds to finance innovation projects (as compared to debt) (OECD, 2010; Revest \& Sapio, 2012).

Subsidized SMEs in our sample finance their R\&D activity primarily via internal funding-on average, about 63 percent of the R\&D expenditures are financed from the internal capital (see the last

\footnotetext{
${ }^{4}$ Still, it would be interesting to test whether the clusters are stable too and/or whether subsidized SMEs transfer from one group to another over time, i.e., whether an intensively supported SME can become, for instance, a supported borrower or a predominantly self-financing SME. But to do this, long-term data on the project grants of subsidized firms is needed.

${ }^{5}$ As it is possible that a firm uses both types of programs, one could suggest that a bivariate probit model might be appropriate at this stage of the econometric analysis. This approach allows for two binary choice equations with correlated disturbances (Greene, 2003). However, since the estimation results from the binary probit model reveal that the correlation coefficient between the error term of the two estimation equations turns out to be insignificant, three univariate probit models are more appropriate here. The three models are for participating in (1) technologyneutral programs only, (2) technology-specific programs only, and (3) using both types of public R\&D promotion programs.
} 
column in Table 2). ${ }^{6}$ Subsidies amount to approximately 30 percent, with bank loans (including subsidized loans) playing only a minor role (5 percent). ${ }^{7}$

In Germany, grants designated for R\&D project costs that are eligible for funding are traditionally the preferred way to promote R\&D and innovation by SMEs. ${ }^{8}$ We distinguish between two types of grants initiated by the German Federal Government, the federal states (Länder) and the EU namely technology-neutral and technology-specific grants. Technology-neutral public support is characterized by the possibility of submitting funding applications with no thematic restriction. On the other hand, in technology-specific support schemes companies apply for a subsidy based upon a unique thematic request of proposals. The technological area of the eligible projects is restricted, mostly to selected high-tech fields. Due to the technological and pre-competitive focus of the supported R\&D projects, technologyspecific programs usually provide larger subsidies to SMEs (between 50 and 70 percent of the R\&D project costs eligible for funding without limits for maximum grants) than technology-neutral programs (between 30 and 50 percent of the R\&D project costs and grants restricted to a maximum, subsidized loans). Various programs employ different selection or ranking criteria for choosing projects and firms. However, the approval rates of technology-neutral programs usually are higher. For the characteristics of main R\&D support programs of the Federal Government for SMEs see Table A2 of the Appendix.

By the means of the cluster analysis, four types of SMEs differing from each other with respect to the financing structure of R\&D can be identified. ${ }^{9}$ Table 2 shows the distribution of subsidized SMEs in

\footnotetext{
${ }^{6}$ Only about 2 percent of SMEs in our sample are companies with external equity investment. Yet, in this case, due to our data, we are not able distinguish between strictly internal capital and equity capital provided by external investors.

${ }^{7}$ Based on the KfW-Mittelstandspanel data, Zimmermann (2010) investigates the financing structure of innovation expenditures for German SMEs. He shows that, on average, 71 percent of innovation expenditures are financed via internal capital, 16 percent through bank loans, 7 percent via public support and the remaining 6 percent through other sources. Compared to our findings, his results show that bank loans (public subsidies) play a more (less) important role in financing structure. Nevertheless, note that he analyzes not only subsidized firms as in our case, on the one hand, and, on the other, he explores the financing structure of innovation and not R\&D activity.

${ }^{8}$ Through 2013 Germany has not had R\&D tax credits, like those commonly used in other OECD countries.

${ }^{9}$ To identify clusters in our study, we use the two-step cluster procedure developed by (Chiu, Fang, Chen, Wang, \& Jeris, 2001) In the first step, the algorithm assigns cases into preclusters that are treated as single cases in the second step. In the second step, forming of clusters occurs employing the standard hierarchical clustering algorithm on the preclusters. We employ this method due to its advantages compared to the traditional cluster procedures (hierarchical clustering and k-means clustering) (Mooi \& Sarstedt, 2011) First, two-step clustering can rapidly form groups on the basis of big datasets allowing thereby for a larger size range of the clusters. In fact, having a segmentation of subsidized SMEs that includes clusters of different sizes has more validity than producing groups of similar size (traditional clustering procedures tend to do this). Second, it is the only clustering procedure that handles a mixture of continuous and categorical variables; this is of high relevance to our study. And, third, the number of clusters can be determined automatically by the algorithm on the basis of the BIC or AIC criterion; in our case, the findings are the same regardless of the used criterion. One disadvantage of the two-step clustering procedure is that it may deliver different results in dependence on sorting of cases (SPSS_Inc., 2001). Our results, however, remain unchanged in light of varying ordering the observations. The further sensitivity analysis shows that clusters determined using sub-samples (e.g., manufacturing firms only) are largely comparable to those presented in Table 2 . Thus, we conclude that our findings from the cluster analysis are robust.
} 
each cluster according to the sources of R\&D financing. A total of 2,708 SMEs went into the analysis and 231 of them could not be assigned to none of the four cluster-largely due to the missing of complete information on the $R \& D$ financing structure. These firms can be described with respect to their $R \& D$ financing pattern as follows:

(1) The first cluster consists of 1,118 SMEs that finance, on average, half of their R\&D expenditure through internal funding and half via public R\&D programs. Accordingly, we label these firms intensively supported SMEs. The average R\&D expenditure in 2010 of this firm group is $217,000 €$.

(2) The second cluster includes only 284 SMEs that use various sources to finance the R\&D activity-i.e., internal funding, public R\&D subsidies, and external R\&D funding (private and public credits). However, note that only these firms place high importance on the latter R\&D funding source. Thus, we name further this group of SMEs as supported borrowers. These firms exhibited relatively high R\&D expenditures in 2010 amounting to about 430,000€, on average.

(3) The third cluster, with 1,016 firms, is similarly relevant among the subsidized SMEs in Germany as the group of intensively supported SMEs. These SMEs engage primarily internal funding (on average, 85 percent of R\&D expenditures) to finance R\&D. Further, they rely also on public aid for R\&D, but to a significantly lesser extent than the cluster described above. They hardly use external funding via credits. We label this firm group self-financing SMEs. On average, these firms spend in 2010 about 500,000€ on the R\&D activity.

(4) The fourth and last cluster is the smallest, consisting of 59 subsidized SMEs only. It contains $R \& D$ firms with $R \& D$ expenditures in excess of the revenue. Consequently, these firms are referred as to $R \& D$ SMEs below. The R\&D expenditure of these companies in 2010 was significantly higher than in the case of other firm groups; it amounted to 1,718,000€, on average. Many of these firms are high-tech start-ups and could probably raise external equity investment. These companies finance, on average, about 50 percent of the R\&D expenditure through internal funding, similarly to the group of intensively supported SMEs. Public R\&D aid (34 percent) and other external funding, like credits (13 percent), comprise the other half of their $R \& D$ expenditure.

[Table 2 near here] 


\section{$4 \quad$ Finance structure and innovation behavior}

\subsection{R\&D and Innovation}

Now that we have built R\&D finance SME groups, we can analyze their innovation behavior. To better depict and interpret the found clusters as distinctive groups of subsidized SMEs, four probit models - which relate the probability of belonging to each cluster to general and innovation-associated characteristics of the firms-are estimated and presented in Table 3. Based on these findings, the four clusters of subsidized SMEs can be described as follows:

Intensively supported SMEs: These firms appear to be significantly smaller and are more frequently based in East Germany, which is a structurally weak region. They engage in exporting to a lesser extent when compared to subsidized SMEs in other groups. Further, they exhibit both a lower R\&D personnel intensity and R\&D effort (measured as R\&D expenditure per R\&D employee), as well as a lower sales share from the new-to-the-market products. Nevertheless, they tend to cooperate in R\&D more frequently than SMEs in the other clusters. Apparently, the rather small firms in the cluster of intensively supported SMEs are less likely to possess all the knowledge and expertise needed to develop and commercialize successfully new technologies and/or other types of innovations. Thus, the R\&D activities of these firms depend on the support of and collaboration with research institutions and other companies to a greater extent than those the larger firms in the other groups. Moreover, intensively supported SMEs attach high importance to the R\&D support programs provided at the Federal Government and EU levels but little relevance to the KfW promotion programs with subsidized loans.

Self-financing SMEs: The firms in this cluster are significantly larger (in terms of number of employees), have higher export intensity, and appear to be less likely to be located in East Germany than other types of publicly supported SMEs. As to R\&D and innovation, they show a higher sales share due to new-to-the-market products and cooperate in R\&D less frequently than other firms. Obviously, these companies have sufficient capacity to successfully undertake R\&D and innovation activity on their own. They use KfW support programs to a lesser extent.

Supported borrowers: Compared to other subsidized SMEs, supported borrowers are more likely to be located in West Germany and tend to be affiliated less frequently with the services sector. Additionally, there are more company spin-offs in this cluster. With respect to public R\&D support, as one could expect, the findings show that these SMEs appear to participate in the programs provided by KfW more often than other types of firms.

$R \& D$ SMEs: Compared to other firm groups, R\&D SMEs show significantly higher R\&D and innovation capacities. R\&D personnel intensity, R\&D effort (measured as R\&D expenditure per R\&D employee), as well as sales share due to new-to-the-market products are all significantly higher for these firms. As one could expect, however, the labor productivity of R\&D SMEs is lower than the one of other 
firms. Moreover, these companies are less likely to be affiliated to the services sector and participate in R\&D promotion programs provided at the Federal Government level.

[Table 3 near here]

In addition, we investigate the distribution of young innovative companies (YICs) across our four groups of subsidized firms. Accordingly to the literature, we define those firms as YICs in our sample that (1) are not older than 5 years, (2) exhibit the R\&D personnel intensity (measured as fraction of R\&D fulltime employees over total employment) higher than 15 percent, and (3) have 10 and more employees. ${ }^{10}$ Looking at the relative frequency distribution of YICs across the four clusters, one might conclude that these firms are more likely to find among the R\&D SMEs (see Table 4). Yet, considering the absolute frequencies, one immediately sees that YICs are particularly strongly represented among self-financing SMEs and intensively supported SMEs. Hence, our results indicate that YICs are not a homogenous firm type with respect to the R\&D financing structure. In other words, different YICs use various funding sources in order to conduct R\&D.

\section{[Table 4 near here]}

\subsection{Participation in public programs}

Among the surveyed SMEs, the vast majority of firms (63 percent) participated in technologyneutral support programs only; one tenth used technology-specific support only, and about 27 percentboth types of public R\&D support. ${ }^{11}$ Accordingly, we estimate three probit models for each combination of types of R\&D promotion from which firms benefit. The corresponding results (presented in Table 5) reveal that, compared to the reference group of self-financing SMEs, intensively supported SMEs attach high importance to both categories of the $R \& D$ support programs, that is, technology-neutral and technology-specific promotion, but are less likely to participate in the latter type of programs only. Further, also supported borrowers appear to use technology-specific support programs only. Finally, R\&D SMEs are less (more) likely to participate in technology-neutral (technology-specific) R\&D support programs only.

Further, the results show that technology-neutral promotion is rather employed by smaller firms, those with a lower R\&D intensity and being affiliated less frequently with the services sector. Technology-specific programs are used more frequently by companies with a lower R\&D intensity and those from the service sector. However, larger firms and those with a higher R\&D intensity are more

\footnotetext{
${ }^{10}$ We use the latter criterion to account for the fact that very small firms may achieve very easily a high R\&D personnel intensity.

${ }^{11}$ Note that, in the case of firm participation in the one type of R\&D support programs only, more than one R\&D project may be supported by one or several programs at the same time.
} 
likely to participate in both types of programs at the same time. This reveals, on the one hand, that SMEs have to have sufficient $R \& D$ capacities in order to use technology-neutral and technology-specific promotion simultaneously. On the other hand, however, this may also simply reflect the fact that firms employing the two categories of support measures have higher needs for R\&D financing. Finally, participating in technology-neutral promotion programs only appears to be associated with the slightest access restrictions.

[Table 5 near here]

\section{Perception of financial and non-financial framework conditions for innovation}

Framework conditions for firm $R \& D$ and innovation include not only that relating to $R \& D$ financing but also those pertaining to market conditions or access to knowledge and information. According to the literature, particularly relevant framework conditions, which may also constitute barriers to innovation, are the availability of internal and external financial funds, the product market regulation, the access to knowledge and information, the supply of qualified R\&D personnel, as well as the appropriability of the innovation's revenues (intellectual property rights) ((Aghion, et al., 2005; Aghion, et al., 2009; Mohnen, et al., 2008; Veugelers, 2008).

In our survey, the companies assessed the importance of fourteen different framework conditions in the areas of financing and market related conditions as well as access to information, on the one hand, and, on the other, the quality of each. Figure 1 shows the relevance of the framework conditions from the viewpoint of subsidized German SMEs. The vast majority of the companies regard the following conditions as highly important: internal financing capacity (91 percent of firms), openness of customers to innovation (85 percent), the access to information on public R\&D support (85 percent) and new technologies (81 percent), as well as fair competitive conditions (78 percent) and the availability of qualified workforce (75 percent). At least, 73 percent of firms consider public support as relevant.

To explore whether firm groups identified in the cluster analysis assess the importance of the particular framework conditions with different levels, we estimate a probit model for each considered framework condition, which relates the probability of attaching a high relevance to a specific framework condition to dummies for belonging to firm clusters and other variables. The corresponding results (presented in Table 6) show some significant differences between the firm groups. Not surprisingly, compared to the reference category self-financing SMEs, the three other clusters attach higher importance to both the state R\&D financing and access to information on public measures for promotion of R\&D and innovation. R\&D SMEs assess internal financing capacity as less important. This is not surprising because many of these firms are probably financed by equity capital. Fair competitive conditions are more 
relevant for intensively supported SMEs and supported borrowers. Further, both intensively supported SMEs and R\&D SMEs attach higher importance to the access to universities and research institutes. The access to information on possible $R \& D$ cooperation partners is particularly important to intensively supported SMEs. This confirms the finding depicted in the previous section that these firms depend strongly on collaboration activities when conducting R\&D due to their size. Nonetheless, both intensively supported SMEs and R\&D SMEs attach lesser relevance to the openness of customers to innovations. The access to information on sales and supply markets, as well as procurement policy in the public sector is more relevant for intensively supported SMEs only. This may be because these firms appear to be at the beginning of the commercializing process of their innovations.

[Figure 1 and Table 6 near here]

As mentioned above, in addition to the importance of various framework conditions, firms assessed also their current quality in Germany (on three-point Likert scale: (1) unfavorable, (2) neutral, and (3) favorable). Figure 2 presents the fractions of firms that assess specific framework conditions as highly important and unfavorable; hence, it shows barriers to R\&D and innovation from the point of view of subsidized German SMEs. Overall, surveyed companies assess various framework conditions for R\&D and innovation activity as quite good. Firms perceive stronger obstacles to innovation only with respect to the availability of skilled labor (about 45 percent of companies that regard this factor as important and unfavorable), followed by laws and standards (approximately 30 percent), as well as fair competitive conditions (20 percent). The finding that only about 9 percent of the firms which assess state R\&D support or external financing by loans as important, regard these framework conditions as unfavorable may be reassuring, especially, when comparing this result to the assessment of other conditions. Nevertheless, note that the surveyed SMEs are all recipients of subsidies; hence, the problem of SMEs' R\&D financing is still a reason for concern.

In order to investigate the differences in the assessments of framework conditions between the identified clusters of subsidized SMEs, we estimate an ordered probit model for each considered framework condition. Table 7 sets out the corresponding results showing the average marginal effects (and standard errors) for the outcome (1) "unfavorable framework condition.” Compared to the reference group of self-financing SMEs, the three other groups of firms view the internal funding capacity as an obstacle to R\&D and innovation. Nevertheless, intensively supported SMEs and R\&D firms are more likely to give higher assessments to public R\&D support. Interestingly, supported borrowers do not perceive the access to credits as a barrier to innovation to a higher extent than the reference category. At first sight, this is a surprising result since the literature generally argues that loans are only difficult to obtain for financing R\&D projects (Blackwell \& Winters, 1997; Cole, 1998; Jaffe, Trachtenberg, \& 
Henderson, 1993; Petersen \& Rajan, 1994; Stiglitz \& Weiss, 1981). However, Meuleman and De Maeseneire (2012) find that receiving a R\&D subsidy implies a positive signal about a SMEs' quality and provides in a better access to long-term debt. Thus, it seems to be very likely that supported borrowers benefit from such positive signals of public R\&D support, and, as a result, appear to have no large difficulties to obtain private external capital via credits to finance R\&D. Nevertheless, R\&D SMEs assess the access to private external R\&D financing (credits) as unfavorable. Obviously, in the case of these firms, the positive signals of public promotion cannot outweigh the problem of a high risk related to their R\&D undertakings. Further, these companies also consider the framework condition laws and standards as unfavorable. Intensively supported SMEs assess better the level of information on new technologies, possible $R \& D$ cooperation partners and public $R \& D$ support measures but are more likely to regard openness of customers to innovations as a barrier to R\&D and innovation. We interpret the latter as an indication that these small firms intend to start the commercialization of their innovations.

[Figure 2 and Table 7 near here]

\section{Discussion and Conclusions}

German subsidized SMEs are quite heterogeneous in financing R\&D and innovation. Two types of firms dominate our sample of subsidized firms: self-financing SMEs with a funding rate of only about 13 percent (the lowest public support quota in the firm sample), on the one hand, and, on the other hand, intensively supported SMEs that finance on average about half of the R\&D expenditure by public grants. With its relatively high funding rate, the $R \& D$ activities of the latter firm group seem to be highly dependent on public R\&D subsidies.

Self-financing SMEs are significantly larger and appear to be less likely to be located in the structurally weak regions of East Germany than other types of publicly supported SMEs. They have higher export quotas and show higher sales shares of innovative products new-to-the-market. Selffinancing SMEs cooperate in R\&D less frequently, indicating that these companies have sufficient capacity to successfully undertake $R \& D$ and innovation activity on their own. In contrast, intensively supported SMEs are relatively small firms that use grants more intensively than all other firm groups. These firms are more likely to be located in East Germany. The R\&D intensity and the R\&D expenditure per R\&D employee are lower than that of the bigger SMEs of the other groups. However, apparently, to compensate the disadvantage of small R\&D capacities, these firms are more active in R\&D cooperation with other companies and research institutes. Intensively supported SMEs are less frequently subsidized by technology-special programs only but use more frequently both technology-neutral and technologyspecial programs. At the time of the survey, their innovation activities were less successful in respect of 
the share of sales of products new-to-the-market. In comparison to self-financing SMEs, they feel more hampered by a lack of openness of customers to innovations but less affected by problems with public subsidies. Overall, we interpret this firm group as small SMEs in an early stage of the innovation process that are well supported by public R\&D promotion.

The two remaining firm groups are significantly smaller. Supported borrowers are the only firm cluster that places high importance on external R\&D funding by private or public credits. Like selffinancing SMEs, supported borrowers are more likely to be located in West Germany. The cluster comprises the highest share of company spin-offs. With respect to public R\&D support, our findings show that the borrowers are less likely to use only technology-specific support programs. This result may reflect that subsidized $R \& D$ projects in this cluster are less frequently cutting-edge and more frequently close to the market. Due to higher financing volumes and lower financial risks, the latter type of projects appears to be more appropriate for support through credits. Concerning the firm assessment of the quality of the other external framework conditions, we hardly find differences between supported borrowers and self-financing firms.

R\&D SMEs form a very small group in our sample. Compared to other firm clusters, these SMEs show significantly higher capabilities for R\&D and innovation. R\&D personnel intensity, R\&D effort, as well as sales share due to new-to-the-market products are all significantly higher for these firms. Like intensively supported SMEs, they use more frequently both technology-neutral and technology-special programs and are less affected by problems with the availability of public R\&D grants. Although both firm groups are more hampered by an insufficient internal financing capacity in comparison to selffinancing SMEs, they seem to be well-supported by R\&D promotion programs. Important differences between these two types of firms are the firm size (intensively supported SMEs are smaller) and the R\&D intensity (which is lower in intensively supported SMEs). R\&D SMEs are more likely to assess laws, standards and other authorization procedures, as well as the availability of loans significantly as innovation barriers. Our results suggest that these firms usually develop product innovations that are close and new to the market and, therefore, they have to cope frequently with product market regulations, i.e., resource and time consuming authorization procedures. In that phase, SMEs also need larger amounts of external finance in the form of loans and face challenges in obtaining them. Consequently, a better access to low interest (subsidized) loans could contribute to mitigate the financing problems of SMEs during the implementation phase of innovation projects.

Overall, our findings suggest that most innovative SMEs in Germany have an easy access to public grants. This is partly due to the significant increase in funding of SME programs as part of the second economic stimulus package (Konjunkturpaket II) to counteract the effects of the global financial and economic crisis in the period 2008 to 2010. Overall, the direct support of SMEs’ R\&D was equivalent 
to about one-quarter of SMEs R\&D expenditures in 2010 (Belitz, Eickelpasch, \& Lejpras, 2013). Not surprisingly, our results indicate high levels of satisfaction of subsidized SMEs with the R\&D and innovation support system in Germany.

Different types of firms use different combinations of grants of technology-neutral and technology-specific programs to pursue their innovation objectives. Indeed, innovative SMEs show different needs for public financial support to $R \& D$ and innovation depending on the importance of $R \& D$ and innovation in the firm and on the development stages of the innovation projects. Moreover, our results show that young innovative companies (YICs) are distributed across all four groups. This indicates that these companies, like other innovative SMEs, utilize different sources for external finance. Thus, we conclude that the success of technology policy does not solely depend on individual support programs but on program portfolios and their interaction. Consequently, SMEs should get the opportunity to select individually the adequate support scheme for their portfolio of innovation projects. Our classification of particular sub-groups of SMEs according to their financing structure of R\&D activity is a step to further develop a comprehensive SME policy, applying specific instruments to target the market failure induced by barriers to financing different bundles of innovation projects of SMEs sub-populations.

Moreover, a successful SME innovation policy needs not only measures to reduce financial constraints but a systemic approach, creating the framework conditions for a favorable environment for innovation (Barbosa \& Faria, 2011). So far, other hampering factors such as shortage of qualified human resources, access to technological information, demand and the competition regulations have received less attention in the innovation literature than financial constraints. This is an unjustified omission which calls for more research into the obstacles to innovative activity (Mohnen, et al., 2008). Our analysis of the assessment of various framework conditions by the subsidized SMEs reveals that companies assess various framework conditions for R\&D and innovation activity as quite good. Firms perceive stronger obstacles to innovation only with respect to the availability of skilled labor, followed by laws and standards, as well as fair competitive conditions. These market-related non-financial conditions are the dominant obstacles to innovation. Only a small part of subsidized SMEs in Germany assesses current public support as important barrier to innovation. Of course, this positive assessment is only made by firms receiving R\&D grants but they represent the great majority of SMEs applying for public support. Our results are in line with (Pellegrino \& Savona, 2013) providing evidence for innovative firms in UK that non-financial systemic types of obstacles have a more important deterring effect than financing problems in limiting SME's ability to innovate.

Finally, another important conclusion of our analysis is that future work in the evaluation of R\&D promotion systems should focus on the interactions of individual programs. In a significant number of SMEs several projects are subsidized simultaneously, by the same or by different programs. Hence, in the 
evaluation of R\&D promotion programs this fact should be taken into consideration. So far, scholars have either evaluated one specific policy instrument or otherwise treatment effects have been derived as averages of different policy interventions. ${ }^{12}$ Analyzing heterogeneous treatments of successive or parallel projects grants resulting in different shares of subsidies in total $R \& D$ expenditures should be the next step to develop a systemic evaluation approach.

\footnotetext{
${ }^{12}$ Only a few studies offer a comparative analysis of different instruments. One example is the study of Dirk; Czarnitzki and Lopes Bento ( 2011), who conduct a multiple treatment effects analysis on the impact that national subsidies compared to, or in combination with, European subsidies have on innovation and R\&D of German companies. In another study, Clausen (2009) analyses whether and how "research" and "development" subsidies stimulate private R\&D and innovation spending, using the actual amount of the subsidies. (Busom, Corchuelo, \& Martinez Ros, 2012) study whether firms' use of R\&D subsidies and R\&D tax incentives are correlated to two sources of underinvestment in R\&D, financing constraints and appropriability. They find that these two instruments do not have the same ability to address each source of $R \& D$ underinvestment.
} 


\section{Tables}

Table 1 Variables used in the empirical analysis.

\begin{tabular}{|c|c|c|}
\hline Variable & Description & Used in: \\
\hline Internal funding & share of internal funding over total R\&D expenditure in 2010 , in \% & Cluster \\
\hline Public R\&D subsidies & $\begin{array}{l}\text { share of public R\&D subsidies over total R\&D expenditure in } 2010 \text {, } \\
\text { in \% }\end{array}$ & Cluster \\
\hline Other external funding (credits) & $\begin{array}{l}\text { share of other external funding (credits) over total R\&D } \\
\text { expenditure in 2010, in \% }\end{array}$ & Cluster \\
\hline R\&D firm (d) & a dummy for a firm with $R \& D$ expenditures greater than sales & Cluster \\
\hline Technology-neutral promotion & $\begin{array}{l}\text { a dummy for participating in technology-neutral public R\&D } \\
\text { support programs over the period 2005-2010 }\end{array}$ & Probit \\
\hline Technology-specific promotion & $\begin{array}{l}\text { a dummy for participating in technology-specific public R\&D } \\
\text { support programs over the period 2005-2010 }\end{array}$ & Probit \\
\hline Firm size (ln) & $\begin{array}{l}\text { logarithm (ln) of the firm size measured as a number of employees } \\
\text { in } 2010\end{array}$ & Probit \\
\hline Research spin-off (d) & a dummy for a spin-off from a university or research institute & Probit \\
\hline Company spin-off (d) & a dummy for a spin-off from another company & Probit \\
\hline East Germany (d) & a dummy for firm location in East Germany & Probit \\
\hline R\&D intensity & share of R\&D employees over total employment in 2010 , in \% & Probit \\
\hline $\begin{array}{l}\text { R\&D expenditure per R\&D } \\
\text { employee }\end{array}$ & R\&D expenditure per R\&D employee in 2010, in EURk & Probit \\
\hline Products new-to-the-market & Sales share due to products new-to-the-market in 2010 , in \% & Probit \\
\hline Products new-to-the-firm & Sales share due to products new-to-the-firm in 2010 , in $\%$ & Probit \\
\hline Cooperation in R\&D & a dummy for cooperation activity in R\&D & Probit \\
\hline Export quote & export/sales ratio in 2010, in \% & Probit \\
\hline Productivity & sales per employee in 2010, in EURk & Probit \\
\hline Manufacturing & a dummy for affiliation with the manufacturing sector & Probit \\
\hline Services & a dummy for affiliation with the service sector & Probit \\
\hline Other sectors & a dummy for affiliation with the other sectors & Probit \\
\hline \multicolumn{3}{|l|}{ Supported via ... } \\
\hline federal programs & a dummy for participation in federal R\&D support programs & Probit \\
\hline Länder programs & a dummy for participation in R\&D support programs of Länder & Probit \\
\hline EU programs & a dummy for participation in the R\&D support programs of the EU & Probit \\
\hline KfW programs & a dummy for participation in R\&D support programs of KfW & Probit \\
\hline
\end{tabular}

Note: Cluster and Probit refer to cluster analysis and probit regressions, respectively. 
Table 2 Types of SMEs according to the financing structure of the R\&D activity (cluster analysis).

\begin{tabular}{|c|c|c|c|c|c|}
\hline & Cluster 1 & Cluster 2 & Cluster 3 & Cluster 4 & Total \\
\hline Cluster name & $\begin{array}{l}\text { Intensively } \\
\text { supported } \\
\text { SMEs }\end{array}$ & $\begin{array}{l}\text { Supported } \\
\text { borrowers }\end{array}$ & $\begin{array}{l}\text { Self-financing } \\
\text { SMEs }\end{array}$ & R\&D SMEs & \\
\hline Internal funding (a) & $\underline{50.08}$ & $\underline{32.31}$ & $\underline{85.79}$ & $\underline{52.85}$ & 62.76 \\
\hline Public R\&D subsidies (a) & $\underline{49.15}$ & 26.28 & 13.22 & 33.95 & 31.43 \\
\hline Other external funding (credits) (a) & 0.77 & $\underline{35.41}$ & 0.99 & 13.19 & 5.13 \\
\hline Total & 100.00 & 100.00 & 100.00 & 100.00 & 100.00 \\
\hline R\&D firm (d) & 0 & 0 & 0 & $\underline{1}$ & 0.02 \\
\hline Number of observations & 1,118 & 284 & 1,016 & 59 & 2,477 \\
\hline R\&D expenditure (in 1000 EUR) & 217 & 427 & 509 & 1,718 & 395 \\
\hline $\begin{array}{l}\text { R\&D expenditure per R\&D employee } \\
\text { (in } 1000 \text { EUR) }\end{array}$ & 43 & 66 & 63 & 374 & 62 \\
\hline
\end{tabular}

Notes: (a) The shares of the respective sources of R\&D financing over total R\&D expenditure (as percentages) in 2010 according to the SMEs types are presented (mean values). (d) denotes a dummy for being a R\&D firm with R\&D expenditures greater than sales. Underlined figures signal the (one or two) most important sources of R\&D financing in each cluster. 
Table 3 The profile of clusters (probit estimates).

\begin{tabular}{|c|c|c|c|c|}
\hline $\begin{array}{l}\text { Dependent variables: } \\
\text { Independent variables: }\end{array}$ & $\begin{array}{l}\text { Intensively } \\
\text { supported } \\
\text { SMEs }\end{array}$ & $\begin{array}{l}\text { Supported } \\
\text { borrowers }\end{array}$ & $\begin{array}{l}\text { Self-financing } \\
\text { SMEs }\end{array}$ & R\&D SMEs \\
\hline Firm size (ln) & $\begin{array}{l}-0.0973^{* * *} \\
(0.013)\end{array}$ & $\begin{array}{l}-0.0026 \\
(0.009)\end{array}$ & $\begin{array}{l}0.0978^{* * *} \\
(0.013)\end{array}$ & $\begin{array}{l}0.0029 \\
(0.003)\end{array}$ \\
\hline Research spin-off (d) & $\begin{array}{l}0.0103 \\
(0.035)\end{array}$ & $\begin{array}{l}-0.0322 \\
(0.026)\end{array}$ & $\begin{array}{l}-0.0206 \\
(0.035)\end{array}$ & $\begin{array}{l}0.0035 \\
(0.005)\end{array}$ \\
\hline Company spin-off (d) & $\begin{array}{l}-0.0030 \\
(0.024)\end{array}$ & $\begin{array}{l}0.0286^{*} \\
(0.015)\end{array}$ & $\begin{array}{l}-0.0318 \\
(0.024)\end{array}$ & $\begin{array}{l}-0.0038 \\
(0.006)\end{array}$ \\
\hline Firms otherwise created (d) & \multicolumn{4}{|c|}{ reference category } \\
\hline East Germany (d) & $\begin{array}{l}0.1384 * * * \\
(0.023)\end{array}$ & $\begin{array}{l}-0.0784^{* * *} \\
(0.017)\end{array}$ & $\begin{array}{l}-0.0856 * * * \\
(0.024)\end{array}$ & $\begin{array}{l}-0.0024 \\
(0.005)\end{array}$ \\
\hline West Germany (d) & \multicolumn{4}{|c|}{ reference category } \\
\hline R\&D intensity & $\begin{array}{l}-0.0018^{* * *} \\
(0.001)\end{array}$ & $\begin{array}{l}-0.0003 \\
(0.001)\end{array}$ & $\begin{array}{l}0.0006 \\
(0.001)\end{array}$ & $\begin{array}{l}0.0005^{* * *} \\
(0.000)\end{array}$ \\
\hline R\&D expenditure per $R \& D$ employee & $\begin{array}{l}-0.0015^{* * *} \\
(0.000)\end{array}$ & $\begin{array}{l}0.0000 \\
(0.001)\end{array}$ & $\begin{array}{l}0.0000 \\
(0.000)\end{array}$ & $\begin{array}{l}0.0002^{* * *} \\
(0.000)\end{array}$ \\
\hline Products new-to-the-market & $\begin{array}{l}-0.002^{* * *} \\
(0.000)\end{array}$ & $\begin{array}{l}0.0004 \\
(0.001)\end{array}$ & $\begin{array}{l}0.0014^{* * *} \\
(0.000)\end{array}$ & $\begin{array}{l}0.0002^{* *} \\
(0.000)\end{array}$ \\
\hline Products new-to-the-firm & $\begin{array}{l}0.0000 \\
(0.000)\end{array}$ & $\begin{array}{l}0.0002 \\
(0.001)\end{array}$ & $\begin{array}{l}-0.0004 \\
(0.000)\end{array}$ & $\begin{array}{l}0.0001 \\
(0.000)\end{array}$ \\
\hline Cooperation in R\&D (d) & $\begin{array}{l}0.0825^{* * *} \\
(0.024)\end{array}$ & $\begin{array}{l}-0.0202 \\
(0.015)\end{array}$ & $\begin{array}{l}-0.0453^{*} \\
(0.024)\end{array}$ & $\begin{array}{l}-0.0041 \\
(0.005)\end{array}$ \\
\hline No cooperation in $R \& D(d)$ & \multicolumn{4}{|c|}{ reference category } \\
\hline Export quote & $\begin{array}{l}-0.0014 * * * \\
(0.000)\end{array}$ & $\begin{array}{l}0.0001 \\
(0.001)\end{array}$ & $\begin{array}{l}0.0018^{* * * *} \\
(0.000)\end{array}$ & $\begin{array}{l}-0.0001 \\
(0.000)\end{array}$ \\
\hline Productivity & $\begin{array}{l}0.0000 \\
(0.000)\end{array}$ & $\begin{array}{l}0.0000 \\
(0.001)\end{array}$ & $\begin{array}{l}0.0001 \\
(0.000)\end{array}$ & $\begin{array}{l}-0.0009 * * * \\
(0.000)\end{array}$ \\
\hline Manufacturing (d) & $\begin{array}{l}-0.0191 \\
(0.027)\end{array}$ & $\begin{array}{l}0.0320^{*} \\
(0.019)\end{array}$ & $\begin{array}{l}-0.0213 \\
(0.027)\end{array}$ & $\begin{array}{l}0.0108^{* *} \\
(0.005)\end{array}$ \\
\hline Other sectors (d) & $\begin{array}{l}0.0330 \\
(0.034)\end{array}$ & $\begin{array}{l}0.0399 * \\
(0.023)\end{array}$ & $\begin{array}{l}-0.1196 * * * \\
(0.036)\end{array}$ & $\begin{array}{l}0.0150^{* *} \\
(0.006)\end{array}$ \\
\hline Services (d) & \multicolumn{4}{|c|}{ reference category } \\
\hline $\begin{array}{l}\text { Supported via ... } \\
\quad \text { federal programs (d) }\end{array}$ & $\begin{array}{l}0.1204^{*} \\
(0.069)\end{array}$ & $\begin{array}{l}0.0407 \\
(0.046)\end{array}$ & $\begin{array}{l}-0.1088 \\
(0.066)\end{array}$ & $\begin{array}{l}-0.0311^{* * *} \\
(0.011)\end{array}$ \\
\hline Länder programs(d) & $\begin{array}{l}0.0356 \\
(0.027)\end{array}$ & $\begin{array}{l}0.0144 \\
(0.018)\end{array}$ & $\begin{array}{l}-0.0361 \\
(0.027)\end{array}$ & $\begin{array}{l}-0.0014 \\
(0.005)\end{array}$ \\
\hline EU programs (d) & $\begin{array}{l}0.0848 * * \\
(0.035)\end{array}$ & $\begin{array}{l}-0.0155 \\
(0.023)\end{array}$ & $\begin{array}{l}-0.0536 \\
(0.036)\end{array}$ & $\begin{array}{l}0.0020 \\
(0.006)\end{array}$ \\
\hline KfW programs (d) & $\begin{array}{l}-0.0876 * * \\
(0.039)\end{array}$ & $\begin{array}{l}0.1135^{* * *} \\
(0.020)\end{array}$ & $\begin{array}{l}-0.1034^{* * *} \\
(0.038)\end{array}$ & $\begin{array}{l}0.0014 \\
(0.008)\end{array}$ \\
\hline $\begin{array}{l}\text { Log likelihood } \\
\mathrm{Chi}^{2}\end{array}$ & $\begin{array}{l}-1,190.4 \\
277.1^{* * *}\end{array}$ & $\begin{array}{l}-625.1 \\
85.7 * * *\end{array}$ & $\begin{array}{l}-1,215.0 \\
171.4^{* * *}\end{array}$ & $\begin{array}{l}-55.1 \\
301.9 * * *\end{array}$ \\
\hline
\end{tabular}

Notes: Reported are the average marginal effects and corresponding standard errors in parentheses. Number of observations is 1,928 . (d) denotes dummy variables. ${ }^{*} \mathrm{p}<0.10$, ${ }^{* *} \mathrm{p}<0.05$, ${ }^{* * *} \mathrm{p}<0.01$. 
Table 4 Distribution of young innovative companies (YIC) across firm groups.

\begin{tabular}{llllll}
\hline & $\begin{array}{l}\text { Intensively } \\
\text { supported } \\
\text { SMEs }\end{array}$ & $\begin{array}{l}\text { Supported } \\
\text { borrowers }\end{array}$ & $\begin{array}{l}\text { Self-financing } \\
\text { SMEs }\end{array}$ & R\&D SMEs & Total \\
\hline Number of all firms & 1.058 & 261 & 953 & 56 & 2.328 \\
Number of YIC & 29 & 11 & 43 & 10 & 93 \\
YIC in \% & 2,7 & 4,2 & 4,5 & 17,9 & 4,0 \\
\hline
\end{tabular}

Notes: YIC refers to young innovation companies. Those are here defined as firms which (1) are not older than 5 years, (2) exhibit the R\&D personnel intensity (measured as fraction of R\&D full-time employees over total employment) higher than 15 percent, and (3) have 10 and more employees.

Table 5 Participation in the technology-neutral and technology-specific public support programs (probit estimates).

\begin{tabular}{|c|c|c|c|}
\hline $\begin{array}{l}\text { Dependent variables: } \\
\text { Independent variables: }\end{array}$ & $\begin{array}{l}\text { Technology-neutral } \\
\text { promotion only }\end{array}$ & $\begin{array}{l}\text { Technology-specific } \\
\text { promotion only }\end{array}$ & $\begin{array}{l}\text { Both technology-neutral } \\
\text { and technology-specific } \\
\text { promotion }\end{array}$ \\
\hline Intensively supported SMEs (d) & $\begin{array}{l}-0.0217 \\
(0.022)\end{array}$ & $\begin{array}{l}-0.0349 * * * \\
(0.013)\end{array}$ & $\begin{array}{l}0.0578^{* * *} \\
(0.020)\end{array}$ \\
\hline Supported borrowers (d) & $\begin{array}{l}0.0354 \\
(0.034)\end{array}$ & $\begin{array}{l}-0.0603 * * * \\
(0.022)\end{array}$ & $\begin{array}{l}0.0225 \\
(0.031)\end{array}$ \\
\hline R\&D SMEs (d) & $\begin{array}{l}-0.2281^{* * *} \\
(0.066)\end{array}$ & $\begin{array}{l}0.0344 \\
(0.037)\end{array}$ & $\begin{array}{l}0.1824^{* * * *} \\
(0.058)\end{array}$ \\
\hline Self-financing SMEs (d) & \multicolumn{3}{|c|}{ reference category } \\
\hline Firm size (ln) & $\begin{array}{l}-0.0930^{* * *} \\
(0.012)\end{array}$ & $\begin{array}{l}-0.0074 \\
(0.007)\end{array}$ & $\begin{array}{l}0.0996^{* * *} \\
(0.011)\end{array}$ \\
\hline R\&D intensity & $\begin{array}{l}-0.0030 * * * \\
(0.000)\end{array}$ & $\begin{array}{l}-0.0007^{* *} \\
(0.000)\end{array}$ & $\begin{array}{l}0.0036^{* * *} \\
(0.000)\end{array}$ \\
\hline Manufacturing (d) & $\begin{array}{l}0.0503^{* *} \\
(0.023)\end{array}$ & $\begin{array}{l}-0.0519 * * * \\
(0.013)\end{array}$ & $\begin{array}{l}0.0046 \\
(0.021)\end{array}$ \\
\hline Other sectors (d) & $\begin{array}{l}0.0810^{* * *} \\
(0.031)\end{array}$ & $\begin{array}{l}-0.0443^{* *} \\
(0.019)\end{array}$ & $\begin{array}{l}-0.0325 \\
(0.029)\end{array}$ \\
\hline Services (d) & \multicolumn{3}{|c|}{ reference category } \\
\hline $\begin{array}{l}\text { Log likelihood } \\
\text { Chi }^{2}\end{array}$ & $\begin{array}{l}-1,473.7 \\
90.1 * * *\end{array}$ & $\begin{array}{l}-683.6 \\
31.7 * * * \\
\end{array}$ & $\begin{array}{l}-1,305.6 \\
112.1^{* * *}\end{array}$ \\
\hline
\end{tabular}

Notes: Reported are the average marginal effects and corresponding standard errors in parentheses. Number of observations is 2,314. The reference categories are self-financing SMEs and service firms. (d) denotes dummy variables. ${ }^{*} \mathrm{p}<0.10,{ }^{* *} \mathrm{p}<0.05,{ }^{* * *} \mathrm{p}<0.01$. 
Table 6 Firm assessment of the importance of framework conditions for firm R\&D and innovative activities (probit estimates).

\begin{tabular}{|c|c|c|c|c|c|}
\hline $\begin{array}{l}\text { Independent variables: } \\
\text { Dependent variables: }\end{array}$ & $\begin{array}{l}\text { Intensively } \\
\text { supported } \\
\text { SMEs (d) }\end{array}$ & $\begin{array}{l}\text { Supported } \\
\text { borrowers (d) }\end{array}$ & R\&D SMEs (d) & $\begin{array}{l}\text { Log } \\
\text { likelihood }\end{array}$ & $\mathrm{Chi}^{2}$ \\
\hline \multirow[t]{2}{*}{ Internal financing capacity } & -0.005 & -0.0297 & $-0.068 * *$ & \multirow[t]{2}{*}{-630.9} & \multirow[t]{2}{*}{$65.71^{* * *}$} \\
\hline & $(0.013)$ & $(0.018)$ & $(0.034)$ & & \\
\hline \multirow[t]{2}{*}{ Private external R\&D financing (credits) } & $0.036^{*}$ & $0.3269 * * *$ & $0.1579 * * *$ & \multirow[t]{2}{*}{$-1,134.4$} & \multirow[t]{2}{*}{$197.6^{* * *}$} \\
\hline & $(0.02)$ & $(0.026)$ & $(0.059)$ & & \\
\hline \multirow[t]{2}{*}{ State R\&D financing } & $0.1597 * * *$ & $0.1069^{* * *}$ & $0.2823^{* * *}$ & \multirow[t]{2}{*}{$-1,234.1$} & \multirow[t]{2}{*}{$76.7^{* * *}$} \\
\hline & $(0.02)$ & $(0.031)$ & $(0.08)$ & & \\
\hline \multirow[t]{2}{*}{ Availability of skilled labor } & -0.02 & -0.0045 & -0.0288 & \multirow[t]{2}{*}{$-1,165.8$} & \multirow[t]{2}{*}{$46.7^{* * *}$} \\
\hline & $(0.02)$ & $(0.031)$ & $(0.061)$ & & \\
\hline \multirow{2}{*}{$\begin{array}{l}\text { Access to universities and research } \\
\text { institutes }\end{array}$} & $0.0524^{* *}$ & -0.0037 & $0.1397 *$ & \multirow[t]{2}{*}{$-1,336.3$} & \multirow[t]{2}{*}{$46.8^{* * *}$} \\
\hline & $(0.021)$ & $(0.033)$ & $(0.074)$ & & \\
\hline \multirow[t]{2}{*}{ Openness of customers to innovations } & $-0.0416^{* *}$ & 0.0053 & $-0.0968 * *$ & \multirow[t]{2}{*}{-896.6} & \multirow[t]{2}{*}{$25.2^{* * *}$} \\
\hline & $(0.017)$ & $(0.026)$ & $(0.048)$ & & \\
\hline \multirow[t]{2}{*}{ Procurement policy in the public sector } & $0.0324 *$ & 0.0188 & -0.064 & \multirow[t]{2}{*}{-950.1} & \multirow[t]{2}{*}{$45.8^{* * *}$} \\
\hline & $(0.019)$ & $(0.028)$ & $(0.065)$ & & \\
\hline \multirow[t]{2}{*}{ Fair competitive conditions } & $0.0393 * *$ & $0.075^{* *}$ & -0.0582 & \multirow[t]{2}{*}{$-1,079.1$} & \multirow[t]{2}{*}{$17.6^{* *}$} \\
\hline & $(0.02)$ & $(0.032)$ & $(0.059)$ & & \\
\hline \multirow{2}{*}{$\begin{array}{l}\text { Laws, standards and other authorisation } \\
\text { procedures }\end{array}$} & -0.0351 & -0.0247 & 0.1097 & \multirow[t]{2}{*}{-474.9} & \multirow[t]{2}{*}{$15.9^{* *}$} \\
\hline & $(0.042)$ & $(0.062)$ & $(0.117)$ & & \\
\hline \multicolumn{6}{|l|}{ Access to information on ... } \\
\hline \multirow[t]{2}{*}{... sales and supply markets } & $0.0416 *$ & -0.0064 & 0.0088 & \multirow[t]{2}{*}{$-1,395.0$} & \multirow[t]{2}{*}{$37.1 * * *$} \\
\hline & $(0.023)$ & $(0.036)$ & $(0.07)$ & & \\
\hline ... new technologies & 0.0283 & -0.0063 & -0.026 & $-1,019.9$ & $14.7 * *$ \\
\hline & $(0.018)$ & $(0.028)$ & $(0.053)$ & & \\
\hline ... the management of innovation & 0.0394 & 0.0291 & 0.0462 & $-1,378.9$ & $25.2 * * *$ \\
\hline processes & $(0.024)$ & $(0.036)$ & $(0.073)$ & & \\
\hline ... possible R\&D cooperation partners & $0.0933 * * *$ & 0.0422 & 0.0278 & $-1,370.5$ & $31.3^{* * *}$ \\
\hline & $(0.022)$ & $(0.034)$ & $(0.07)$ & & \\
\hline ... public measures for promotion of & $0.1339 * * *$ & $0.0639 * *$ & 0.1023* & -888.6 & $74.3 * * *$ \\
\hline R\&D and innovation & $(0.017)$ & $(0.025)$ & $(0.057)$ & & \\
\hline
\end{tabular}

Notes: The dependent variables in the probit models-i.e., firm assessment of the importance of framework conditions takes the value of 1 if the corresponding framework condition is of high importance to a firm, and 0 otherwise. Reported are the average marginal effects and corresponding standard errors in parentheses. In the models, we control also for firm size, R\&D intensity and economic sector; the estimates for those covariates are not shown for the sake of brevity. (d) denotes dummy variables. The reference category is the group of self-financing SMEs. ${ }^{*} \mathrm{p}<0.10,{ }^{* *} \mathrm{p}<0.05,{ }^{* * *} \mathrm{p}<0.01$. 
Table 7 Firm assessment of the quality of framework conditions for firm R\&D and innovative activities (ordered probit estimates).

\begin{tabular}{|c|c|c|c|c|c|}
\hline $\begin{array}{l}\text { Independent variables: } \\
\text { Dependent variables: }\end{array}$ & $\begin{array}{l}\text { Intensively } \\
\text { supported } \\
\text { SMEs (d) }\end{array}$ & $\begin{array}{l}\text { Supported } \\
\text { borrowers (d) }\end{array}$ & R\&D SMEs (d) & $\begin{array}{l}\text { Log } \\
\text { likelihood }\end{array}$ & Chi2 \\
\hline \multirow[t]{2}{*}{ Internal financing capacity } & $0.0236^{*}$ & $0.103^{* * *}$ & $0.1467 * * *$ & \multirow[t]{2}{*}{$-2,128.5$} & \multirow[t]{2}{*}{$63.0^{* * *}$} \\
\hline & $(0.012)$ & $(0.019)$ & $(0.039)$ & & \\
\hline \multirow[t]{2}{*}{ Private external R\&D financing (credits) } & 0.0123 & -0.036 & $0.1222 *$ & \multirow[t]{2}{*}{$-1,849.4$} & \multirow[t]{2}{*}{$90.5^{* * *}$} \\
\hline & $(0.02)$ & $(0.03)$ & $(0.065)$ & & \\
\hline \multirow[t]{2}{*}{ State R\&D financing } & $-0.0738 * * *$ & -0.0219 & $-0.1023^{* *}$ & \multirow[t]{2}{*}{$-1,958.0$} & \multirow[t]{2}{*}{$50.5^{* * *}$} \\
\hline & $(0.012)$ & $(0.019)$ & $(0.04)$ & & \\
\hline \multirow[t]{2}{*}{ Availability of skilled labor } & $-0.0399 *$ & -0.0086 & 0.0309 & \multirow[t]{2}{*}{$-1,878.8$} & \multirow[t]{2}{*}{$22.6^{* * *}$} \\
\hline & $(0.022)$ & $(0.034)$ & $(0.071)$ & & \\
\hline \multirow{2}{*}{$\begin{array}{l}\text { Access to universities and research } \\
\text { institutes }\end{array}$} & -0.011 & 0.001 & -0.0296 & \multirow[t]{2}{*}{$-1,810.6$} & \multirow[t]{2}{*}{$21.5^{* * *}$} \\
\hline & $(0.007)$ & $(0.011)$ & $(0.024)$ & & \\
\hline \multirow[t]{2}{*}{ Openness of customers to innovations } & $0.0151^{* *}$ & 0.0045 & 0.0062 & \multirow[t]{2}{*}{$-1,797.5$} & \multirow[t]{2}{*}{$16.5^{* *}$} \\
\hline & $(0.007)$ & $(0.011)$ & $(0.022)$ & & \\
\hline \multirow[t]{2}{*}{ Procurement policy in the public sector } & -0.0077 & 0.0342 & -0.0484 & \multirow[t]{2}{*}{$-1,319.6$} & \multirow[t]{2}{*}{$27.84 *$} \\
\hline & $(0.022)$ & $(0.034)$ & $(0.069)$ & & \\
\hline \multirow[t]{2}{*}{ Fair competitive conditions } & -0.0131 & -0.0028 & -0.0468 & \multirow[t]{2}{*}{$-1,622.9$} & \multirow[t]{2}{*}{$22.2^{* *}$} \\
\hline & $(0.017)$ & $(0.026)$ & $(0.056)$ & & \\
\hline \multirow{2}{*}{$\begin{array}{l}\text { Laws, standards and other authorisation } \\
\text { procedures }\end{array}$} & -0.0287 & 0.0067 & $0.1811^{*}$ & \multirow[t]{2}{*}{-542.8} & \multirow[t]{2}{*}{$12.9 *$} \\
\hline & $(0.036)$ & $(0.052)$ & $(0.098)$ & & \\
\hline \multicolumn{6}{|l|}{ Access to information on ... } \\
\hline \multirow[t]{2}{*}{... sales and supply markets } & -0.0196 & 0.0311 & 0.0366 & \multirow[t]{2}{*}{$-1,614.5$} & \multirow[t]{2}{*}{$12.3^{*}$} \\
\hline & $(0.013)$ & $(0.019)$ & $(0.04)$ & & \\
\hline ... new technologies & $-0.0123^{*}$ & $0.03^{* * *}$ & 0.0242 & $-1,659.6$ & $37.0^{* * *}$ \\
\hline & $(0.007)$ & $(0.011)$ & $(0.022)$ & & \\
\hline ... the management of innovation & $-0.0209 * *$ & 0.0197 & 0.022 & $-1,250.7$ & $17.3^{* *}$ \\
\hline processes & $(0.01)$ & $(0.015)$ & $(0.031)$ & & \\
\hline ... possible R\&D cooperation partners & $-0.0344 * * *$ & 0.0065 & 0.0073 & $-1,683.7$ & $22.5^{* * *}$ \\
\hline & $(0.01)$ & $(0.014)$ & $(0.029)$ & & \\
\hline ... public measures for promotion of & $-0.0479 * * *$ & -0.0115 & -0.048 & $-1,823.9$ & $39.6^{* * *}$ \\
\hline R\&D and innovation & $(0.01)$ & $(0.015)$ & $(0.03)$ & & \\
\hline
\end{tabular}

Notes: The dependent variables in the ordered probit models-i.e., the quality of various framework conditions is assessed by firms on three-point Likert scale: (1) unfavorable, (2) neutral, and (3) favorable. Reported are the average marginal effects and corresponding standard errors in parentheses for the outcome (1), that is, those for unfavorable framework conditions. In the models, we control also for firm size, R\&D intensity and economic sector; the estimates for those covariates are not shown for the sake of brevity. (d) denotes dummy variables. The reference category is the group of self-financing SMEs. ${ }^{*} \mathrm{p}<0.10,{ }^{* *} \mathrm{p}<0.05,{ }^{* * *} \mathrm{p}<0.01$. 


\section{Figures}

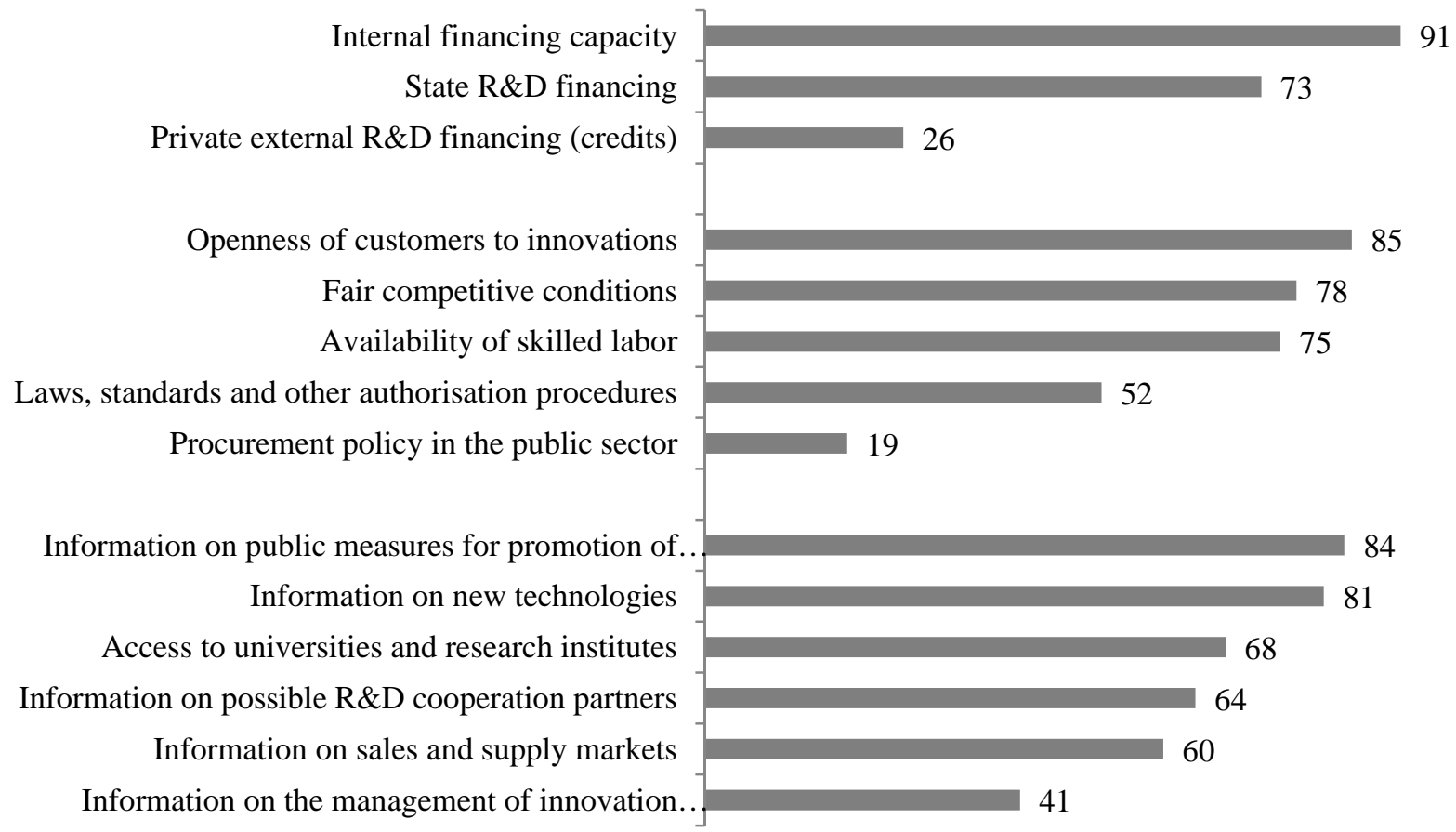

Figure 1 Importance of framework conditions.

Note: Reported are the fractions of firms that view the respective framework condition as highly important (as percentages). 


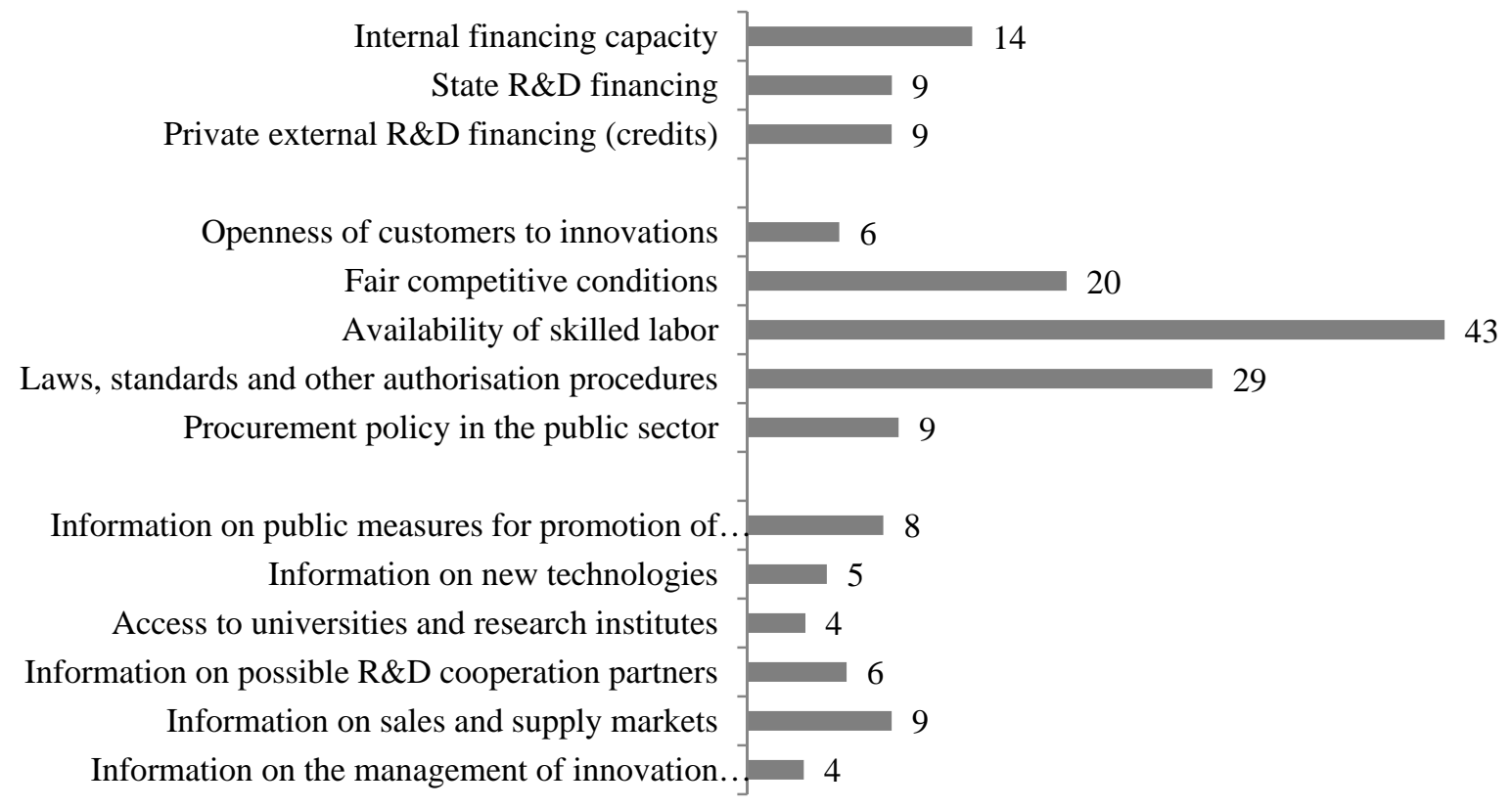

\section{Figure 2 Assessment of framework conditions.}

Note: Reported are the fractions of firms that view the respective framework condition as highly important and assess it as unfavorable (as percentages). 


\section{Appendix}

Table A 1 Descriptive statistics—sample characteristics

\begin{tabular}{|c|c|c|c|}
\hline \multirow[b]{2}{*}{ Variables } & \multicolumn{3}{|c|}{ Subsidized SMEs } \\
\hline & $\mathrm{N}$ & Mean & SD \\
\hline \multicolumn{4}{|l|}{ Firm size (in employees) in 2010} \\
\hline up to 5 & 2,708 & 0.134 & 0.340 \\
\hline 6 to 19 & 2,708 & 0.392 & 0.488 \\
\hline 20 to 49 & 2,708 & 0.265 & 0.441 \\
\hline 50 to 99 & 2,708 & 0.119 & 0.324 \\
\hline 100 and more & 2,708 & 0.090 & 0.286 \\
\hline Research spin-off & 2,708 & 0.124 & 0.329 \\
\hline Company spin-off & 2,708 & 0.330 & 0.470 \\
\hline East Germany & 2,708 & 0.355 & 0.479 \\
\hline West Germany & 2,708 & 0.645 & 0.479 \\
\hline $\begin{array}{l}\text { R\&D intensity ( } N \text { of R\&D employees over total } \\
\text { employment) in } 2010\end{array}$ & 2,524 & 32.8 & 27.3 \\
\hline $\begin{array}{l}\text { R\&D effort (R\&D expenditure per R\&D employee; } \\
\text { kEUR) in } 2010\end{array}$ & 2,293 & 61.6 & 267.5 \\
\hline Sales share due to products new to the market in 2010 & 2,405 & 23.5 & 25.9 \\
\hline Sales share due to products new to the firm in 2010 & 2,377 & 25.2 & 27.4 \\
\hline R\&D cooperation activity & 2,611 & 0.656 & 0.475 \\
\hline Export quote in 2010 & 2,383 & 25.0 & 25.9 \\
\hline Productivity in 2010 & 2,456 & 129.5 & 196.2 \\
\hline \multicolumn{4}{|l|}{ Industry } \\
\hline Manufacturing & 2,708 & 0.528 & 0.499 \\
\hline Services & 2,708 & 0.306 & 0.461 \\
\hline Other sectors & 2,708 & 0.167 & 0.373 \\
\hline $\begin{array}{l}\text { Suported in 2005-2010 via... } \\
\text { federal programs }\end{array}$ & 2,522 & 0.969 & 0.173 \\
\hline Länder programs & 2,522 & 0.263 & 0.441 \\
\hline EU programs & 2,522 & 0.120 & 0.325 \\
\hline KfW programs & 2,522 & 0.091 & 0.288 \\
\hline
\end{tabular}

Notes: $\mathrm{N}$ and SD refer to the number of observations and standard deviation, respectively. 
Table A2 Characteristics of main R\&D support programs of the German Federal Government for SMEs in 2010.

\begin{tabular}{|c|c|c|c|c|}
\hline $\begin{array}{l}\text { Name of the } \\
\text { program }\end{array}$ & ZIM-SOLO & ZIM-KOOP & KMU-innovativ & Specialist programs \\
\hline Promoting agent & \multicolumn{2}{|c|}{$\begin{array}{c}\text { Federal Ministry of Economics and } \\
\text { Technology }\end{array}$} & \multicolumn{2}{|c|}{$\begin{array}{c}\text { Federal Ministry of Education and } \\
\text { Research }\end{array}$} \\
\hline $\begin{array}{l}\text { Technology } \\
\text { orientation }\end{array}$ & \multicolumn{2}{|c|}{ Technology-neutral } & \multicolumn{2}{|c|}{ Technology-specific } \\
\hline Type of projects & Single projects & $\begin{array}{l}\text { Collaborative } \\
\text { projects }\end{array}$ & $\begin{array}{l}\text { Single and } \\
\text { collaborative } \\
\text { projects }\end{array}$ & $\begin{array}{l}\text { Single and } \\
\text { collaborative } \\
\text { projects }\end{array}$ \\
\hline $\begin{array}{l}\text { Submission of } \\
\text { proposals }\end{array}$ & Continuously & Continuously & Six-monthly & $\begin{array}{l}\text { Irregular tenders to } \\
\text { application }\end{array}$ \\
\hline Approval rate & $66 \%^{1)}$ & $66 \%{ }^{1)}$ & $19 \%^{2)}$ & Not available \\
\hline Support quota & $35-45 \%$ & $40-50 \%$ & $50-70 \%$ & $50-70 \%$ \\
\hline Maximum grant & 157,500 & 175,000 & No limit & No limit \\
\hline $\begin{array}{l}\text { Average grant per } \\
\text { SME and project } \\
\text { (in euros) }\end{array}$ & 116,000 & 117,000 & 248,000 & 291,000 \\
\hline $\begin{array}{l}\text { Length of a typical } \\
\text { project }\end{array}$ & $1-2$ years & $1,5-3$ years & 2 years & 3 years \\
\hline $\begin{array}{l}\text { Total subsidies to } \\
\text { SMEs in } 2010 \text { (in } \\
\text { million euros) }\end{array}$ & 150 & 219 & 47 & 225 \\
\hline $\begin{array}{l}\text { Awarding of grants } \\
\text { per year }\end{array}$ & $1300^{1)}$ & $2250^{1)}$ & $281^{2)}$ & $770^{1)}$ \\
\hline
\end{tabular}

Notes: 1) Average of the period 2008 - 2010. 2) Average of the period 2007 - 2010.

Sources: Rammer et al. (2011), Federal Ministry of Economics and Technology; Own estimations. 


\section{References}

Aghion, P., Bloom, N., Blundell, R., Griffith, R., \& Howitt, P. (2005). Competition and Innovation: an Inverted-U Relationship. The Quarterly Journal of Economics, 120(2), 701-728.

Aghion, P., Blundell, R., Griffith, R., Howitt, P., \& Prantl, S. (2009). The Effects of Entry on Incumbent Innovation and Productivity. The Review of Economics and Statistics, 91(1), 20-32.

Aschhoff, B. (2010). Who Gets the Money? The Dynamics of R\&D Project Subsidies in Germany. Journal of Economics and Statistics (Jahrbuecher fuer Nationaloekonomie und Statistik), 230(5), 522-546.

Barbosa, N., \& Faria, A. P. (2011). Innovation across Europe: How important are institutional differences? Research Policy, 40(9), 1157-1169.

Belitz, H., Eickelpasch, A., \& Lejpras, A. ( 2013). Innovation Policy for SMEs Proves Successful DIW Economic Bulletin (Vol. 3, pp. 11-19): DIW Berlin, German Institute for Economic Research.

Blackwell, D. W., \& Winters, D. B. (1997). Banking Relationships and the Effect of Monitoring on Credit Pricing. The Journal of Financial Research, 20(2), 275-289.

Busom, I., Corchuelo, B., \& Martinez Ros, E. (2012). Tax incentives or subsidies for R\&D? UNU-MERIT Working Paper Series.

Chiu, T., Fang, D., Chen, J., Wang, Y., \& Jeris, C. (2001). A robust and scalable clustering algorithm for mixed type attributes in large database environment. Paper presented at the Proceedings of the seventh ACM SIGKDD international conference on Knowledge discovery and data mining, San Francisco, California.

Clausen, T. H. (2009). Do subsidies have positive impacts on R\&amp;D and innovation activities at the firm level? Structural Change and Economic Dynamics, 20(4), 239-253.

Cole, R. (1998). The Importance of Relationships to the Availability of Credit. Journal of Banking and Finance, 22, 959-977.

Czarnitzki, D., \& Delanote, J. (2012). Young innovative companies: The new high-growth firms? In Z.-Z. f. E. W. C. f. E. E. Research (Ed.), ZEW Discussion Papers.

Czarnitzki, D., \& Lopes Bento, C. ( 2011). Innovation subsidies: Does the funding source matter for innovation intensity and performance? Empirical evidence from Germany Open Access publications from Katholieke Universiteit Leuven. Katholieke Universiteit Leuven.

Evangelista, R., \& Vezzani, A. (2010). The economic impact of technological and organizational innovations A firm-level analysis. Research Policy, 39(10), 1253-1263.

Greene, W. H. (2003). Econometric analysis (5th ed.). London: Prentice Hall International.

Hall, B. H. (2010). The Financing of Innovative Firms (Vol. 1).

Hashi, I., \& Stojcic, N. ( 2010). The Impact of innovation activities on firm performance using a multistage model: evidence from the Community Innovation Survey 4 CASE Network Studies and Analyses.

Hollenstein, H. (2003). Innovation modes in the Swiss service sector: a cluster analysis based on firmlevel data. Research Policy, 32(5), 845-863.

Hölzl, W., \& Janger, J. (2012). Innovation Barriers across Firms and Countries WIFO Working Papers.

Jaffe, A. B., Trachtenberg, M. H., \& Henderson, R. (1993). Geographic localization of knowledge spillovers as evidenced by patent citations. . Quarterly Journal of Economics, 108, 577-598.

Meuleman, M., \& De Maeseneire, W. (2012). Do R\&D subsidies affect SMEs’ access to external financing? Research Policy, Volume 41(Issue 3), Pages 580-591.

Mohnen, P., Palm, F. C., Loeff, S. S., \& Tiwari, A. (2008). Financial Constraints and Other Obstacles: are they a Threat to Innovation Activity? De Economist, 156(2), 201-214.

Mooi, E., \& Sarstedt, M. (2011). Cluster Analysis A Concise Guide to Market Research: The Process, Data, and Methods Using IBM SPSS Statistics (pp. 237-284). Berlin Heidelberg: SpringerVerlag. 
OECD. (2010). High-Growth Enterprises: What Govenments can do to make a difference. OECD Studies on SMEs and Entrepreneurship. Paris.

Pellegrino, G., \& Savona, M. (2013). No Money, No honey? Financing versus Knowledge and Demand Constraints to Innovation. In J. R. C.-I. f. P. T. S. European Commission (Ed.), Contributed paper to be presented at the 4th European Conference on Corporate R\&D and Innovation CONCORDi-2013, September 26-27 2013, Seville (Spain), Financing R\&D and innovation for corporate growth in the EU: Strategies, drivers and barriers.

Petersen, M. A., \& Rajan, R. G. (1994). The Benefits of Lending Relationships: Evidence for Small Business Data, ), . The Journal of Finance, 49(1), 3-37.

Revest, V., \& Sapio, S. (2012). Financing technology-based small firms in Europe: what do we know? Small Business Economics, 39(1), 179-205.

Schneider, C., \& Veugelers, R. (2010). On young highly innovative companies: why they matter and how (not) to policy support them. Industrial and Corporate Change, 19(4), 969-1007.

SPSS_Inc. (2001). The SPSS TwoStep Cluster Component: A Scalable Component Enabling More Efficient Customer Segmentation. Technical Report. Chicago, IL.

Stiglitz, J., \& Weiss, A. (1981). Credit Rationing in Markets with Imperfect Information. American Economic Review, 71, 393-410.

Tanayama, T. (2009). Rationales and reality of R\&D subsidies: Are SMEs and large firms treated differently? Helsinki Center of Economic Research Discussion Paper

Veugelers, R. (2008). The Role of SMEs in Innovation in the EU: A Case for Policy Intervention? Business and Economics, LIII(3), 239-262.

Zúñiga-Vicente, J., Alonso-Borrego, C., Forcadell, F. J., \& Galán, J. I. (2012). ASSESSING THE EFFECT OF PUBLIC SUBSIDIES ON FIRM R\&D INVESTMENT: A SURVEY. Journal of Economic Surveys, Early View (Online Version of Record published before inclusion in an issue). 